\title{
SLEEPING ON THE STREETS: A PERSPECTIVE OF MIGRATION IN THE BORDER OF REYNOSA TAMAULIPAS, MEXICO
}

\section{CYNTHIA MARISOL VARGAS OROZCO}

\begin{abstract}
:
This exploratory study describes the main problems that the migrants face when sleeping and living in the streets of Reynosa, Tamaulipas. In order to make visible the living conditions of migrants in street situation once they have been deported or have arrived in the city looking to cross into the United States, an interview was structured and 8 people were found in the streets near the international bridge Reynosa-Hidalgo and near the lodging houses for migrants. As a result, the number of migrants arriving in the city exceeds the capacity of the assistance houses to accommodate all migrants who need it, as well as the intention of the people to return to the United States and the lack of economic resources to pay again to cross illegally or return to their places of origin. This situation results in migrants sleeping on the streets, alleys and makeshift houses, exposing themselves to aggressions by structural elements of the State and local criminal groups.
\end{abstract}

\section{Keywords:}

migration, border, homeless, sleeping on the streets

JEL Classification: K21, J61, J15

\section{Authors:}

CYNTHIA MARISOL VARGAS OROZCO, Universidad Autónoma de Tamaulipas, Mexico, Email: cmvargas@uat.edu.mx

\section{Citation:}

CYNTHIA MARISOL VARGAS OROZCO (2020). SLEEPING ON THE STREETS: A PERSPECTIVE OF MIGRATION IN THE BORDER OF REYNOSA TAMAULIPAS, MEXICO. International Journal of Social Sciences, Vol. IX(1), pp. 113-131., 10.20472/SS.2020.9.1.007 


\section{INTRODUCTION}

Migration represents one of the most prevalent social phenomena at present, the problems of public security, drug trafficking and struggles between criminal groups in the last decade in Mexico and the security policies of President Trump in the United States, have resulted in a tightening of migration policies with a considerable impact on the border cities of northern Mexico and traditional migration processes. Deriving from the constant presence and permanence of migrants in the streets near the border crossing and in the surroundings of the migrant housing houses, performing temporary jobs and sleeping on public roads and / or makeshift places in the streets of Reynosa, the This study seeks to understand the migrant scenario in the streets as a current manifestation of the migration phenomenon in the city.

The city of Reynosa is located on the northeastern border of Mexico, bordering the State of Texas in the United States, and geographically it is the closest border point from central and southern Mexico and the Central American region (Canales y Rojas, 2018) . This situation historically has allowed this border area to become a strategic point for the trafficking of drugs, weapons and people (Correa, 2016) including the establishment of criminal groups that traffic, fight and compete to obtain better territories for these activities, that has resulted in the increase in insecurity in recent decades and where migration as a social phenomenon coincides with that of public insecurity. Therefore, people seeking to reach the United States are in an environment of vulnerability and risk (Vargas and Villarreal, 2008) that makes the migration process difficult.

So the present study describes the scenario of migration on the streets of the city through the experiences of these people, allowing us to propose a different context of migration in the region and the migration phenomenon in Mexico, which makes visible the conditions under which the American dream is sought.

\section{Migration and its challenges}

Migration is understood as "the movement of the population towards the territory of another State or within it that encompasses any movement of people, regardless of their size, composition or causes; it includes migration of refugees, displaced persons, uprooted people and economic migrants "(International Organization for Migration (IOM), 2013) and 
according to the Center for Social Studies and Public Opinion (CESOP) (2015) 40\% of the mobilizations are to the neighboring country.

The region of Mexico and Central America has been characterized by an increase in the numbers of international migration in the last two decades, as well as its complexity, highlighting that the United States is the main recipient of Mexican and Central American emigration, by 2015 97\% of Migrants in the United States were Mexicans (Canales and Rojas, 2018), a condition that in addition to security policies in the American nation, have resulted in the tightening of migration policies, forcing migrants and traffickers to seek new strategies of illegal entry into the American territory.

Among the main obstacles that people face in their migratory journey, beyond economic needs, lack of social security, etc., the violence has become part of the migration process, it has been well documented that during the migration, individuals face to situations that compromise their physical security and emotional state, violent events, the transfer of great distances, exploitation and humiliation result in attitudes of distrust towards the social environment (Ravenstein, 1989, Thomas and Znaniecki, 2004, Vargas and Villarreal, 2008 and Izcara, 2012). This condition of disadvantage places migrants in situations of violence from the social environment towards them and from them to the environment, in this sense, during migration they face four types of violence: personal / direct, structural / indirect, cultural and finally post-structural violence (Galtung, 1969, 1990; cited in Izcara, 2012).

Mexico being a country of migratory transit, on the way migrants are exposed to the national social problems, such as insecurity for the fight between criminal groups and lack of development in some places; According to the data of the Survey on Migrant Aggression and Abuse (EAAM) (2012), migrants are a highly vulnerable population and exposed to various risks and dangers, among which the actions of organized drug trafficking gangs and of human trafficking, as well as the weakness of the policy and intervention of the Mexican government, which although in its formulation is based on a rights approach, this is usually absent at the time of its application (Canales y Rojas, 2018).

This is a serious problem caused by the massive flight from places of origin due to violence, poverty and social exclusion, and by the containment policies that oblige Central American migrants, including many children and adolescents, to crossing through Mexico, exposing oneself to the risks implied by the presence and action of organized gangsters and 
traffickers, among other risks of crossing and irregular transit through this country (Orozco and Yansura, 2015, cited in Canales y Rojas, 2018, p. 18 ).

The common discourse in academic and government reports is that migration improves the living conditions of those who decide to migrate, based on the fact that the main reasons are economic according to traditional migratory theories; however, this hypothesis does not contemplate the territorial dimension, since space plays a fundamental role in the migration process, the social, security and economic conditions under which migration generally occurs; the space makes it difficult for these people to enter labor markets due to the characteristics of the new place of residence, while some places may have mediocre development opportunities and the resources to progress are inaccessible to all, adding structural components of poverty, ethnicity and racial, etc. As far as the study of migration from the territorial context is concerned, because specialized literature has not paid enough attention and the migration studies generally perceived it as a form of displacement (Delaunay, 2007, p. 89).

Among the work done in Mexico on the relationship of territory and migration, the study realized by the International Organization for Migration (2010) called: "Central American migrant children and adolescents in populations in southern Mexico" it has been based on the need to know the characteristics of the migration of this population, managing to address two aspects of migration that had not deepened: children and adolescents and migrants "who stay" in Mexican territory, emphasizing the study in workers in street situation, domestic workers and agricultural workers. In the study it was found that these social groups are engaged to informal work activities such as shoe cleaners (boleros), windshield wipers, beggars and market chargers, as well as food stand, however, due to the characteristics of these groups (children) they are vulnerable to be victims of human trafficking and are subjected to abuse by those responsible for regulating the informal market.

\section{Migration in Reynosa: migrants in transit and deported}

Without stopping in the migration statistics in the region for reasons of extension of the document, it is highlighted that the city of Reynosa is characterized as a place of transit, destination of migration and deportation (Canales and Rojas, 2018). Generally, internal migration is characterized by people from states such as San Luis Potosí, Veracruz, Nuevo Leon, Mexico City and Coahuila and other states in central and southern Mexico (INEGI, 2015), and arrive in the city in search of opportunities labor, also of people looking to cross 
into the United States and stop in the city to rest and organize to cross; and finally as a place of deportation by the American immigration authorities.

The city of Reynosa is an important crossing point through international bridges, and American immigration authorities deport migrants through these bridges, only in the 20142018 period these deportations accounted for $8.5 \%$ of the total of national deportations (Survey on Migration in the Northern Border of Mexico (EMIF), 2018), so it is common that deportations of people from this city from various parts of the United States are carried out every two months.

The return and deportations of migrants represent a new dimension of the migration process (Gandini, Lozano and Gaspar, 2015; Lozano and Martínez, 2015), only in the 2005-2010 period the return data reached a record of more of 825 thousand people deported in Mexico, while returning the National Survey of Geographical Dynamics from 2004 to 2014, represents a decrease of 490729 in 2004 to 264055 migrants in return in 2014, continuing downward until 37190 in 2016 (Montoya, Alcántar and Jauregui, 2018). The deportations and return migration have become another fundamental element of the study of migration in Mexico (National Population Council, 2018), so it is essential to identify the needs of the nationals in new scenarios of importance for national migration policies.

\section{Living on the street, theoretical aspects to understand the phenomenon}

The definition of "street population" includes any person or group of person with or without relation to each other, who subsist on the street or the public space using their own and precarious resources to satisfy their elementary needs (Council to Prevent and Eliminate Discrimination (COPRED), 2017) and are constituted as "a historical subject that builds a cultural identity resulting from social exclusion" (Coordinating Committee for the Development of the Diagnosis and Human Rights Program of the Federal District, 2008).

COPRED (2017) establishes that the street situation not only includes the status of housing, but also the phenomenon associated with extreme poverty in cities, forcing people to live in streets, paths, squares, bridges, abandoned buildings, cars, etc., using institutionally recognized places such as shelters, welfare homes and makeshift housing (Tiraboschi, 2011) derived from a precarious economic situation, weak family ties and the lack of regular conventional housing. 
Moreno, Espinoza and Zapata (2017) establish that social groups in a street situation are formed within the community that lives in the same context and differ according to age, gender, activity from which they obtain sustenance, the space in which they live and mental health conditions, highlighting those who do not form groups and carry out their activities independently, which make them vunerable to being victims of violence by other habitants of the street or be forced to belong to criminal groups.

In addition to the external risks of living on the street, people can suffer considerable damage in their psychic and organic constitution, the absence of a roof is an important situation of insecurity that can cause fear, uprooting and lack of privacy, as Navarro argues ( 2014) Some of the consequences of staying on the street may result in the individual's personal risk:

"Embarrassment of sleeping on the street, feelings of failure of the immigration project, social stigma, feelings of dehumanization, thoughts of not being a dignified person in society, a being useful for society, alienation, sadness, recurring thoughts and rumination of situation, irascibility, changes in personal identity, lack of control over one's life, temporal perspective of immediacy, anomie and in some cases hopelessness. "(Navarro, 2014, p. 2)

In this context, the migratory conditions and the continuous and recurrent displacements of the population in border contexts, configure specific frameworks of social and demographic vulnerability, especially with regard to human rights (Canales and Rojas, 2018), especially when these social groups they have experienced situations of violence on the migratory path; Given the diversity of situations faced by migrants, living and sleeping on the street has remained on the periphery of research, as mentioned previously by the IOM study (2018) on children and adolescents, has It has been the study that has approached the context of migrants on the street in Mexico, with emphasis on minors, however, it is still pending to understand how adult migrants experience living on the street on the northern border of Tamaulipas. 


\section{METHODOLOGY}

\section{Methodological perspective}

The process of approaching to the life of migrants in the street situation in Mexico is complex, Blummer (1969) uses the metaphor of "unveiling" or lifting the veil to know and understand a phenomenon that seems hidden, so the present study seeks to make a first approach to this social phenomenon as a cardinal principle of the nature of the empirical world directly from the perception of the protagonists, and as stated by Denzin (1997) who seeks to understand a phenomenon must be affected and modified by contact with subjects and objects of study, which resulted in the methodological position of the present being qualitative.

Through this method, semi-structured interviews were carried out, applied in the street, the people interviewed were not chosen in a random way, but rather they sought to comply with the specifications that allowed to understand the phenomenon directly from their experiences, allowing reflections, descriptions and interpretations of their reality.

\section{Description of the technique and procedure for applying the interviews}

To obtain the information, semi-structured interviews were conducted, based on four previous categories: migratory dynamics, living on the street, subsistence work and the risks of living in a street situation.

The category of migratory dynamics is aimed to understanding where the migrant come from and where they're going or if they are passing through the city waiting to cross into the United States, and allow us deepening to family relationships, life projects and short, medium or long term ovjetives. The category of living in the street identifies the places where they reside in the city through their discourse and their experiences, the strategies used to get the place where they live and the conditions in which they live; this last point is related to the category of work as subsistence, which identifies the main activities they carry out to obtain resources to survive; and finally, the category of the risks of living in a street situation, makes visible the risks to which they are exposed when living in the street and the strategies they use to face them.

To carry out the interviews, tours were taken along the streets near the Reynosa-Hidalgo international bridge and near the migrant assistance houses of the city (Casa del Migrante 
Nuestra Señora de Guadalupe and Senda de Vida), although in the area it is common to see migrants, not all of them remain in the city for a long time and not all people allow to be interviewed for fear that personal data will be revealed due to the conditions of insecurity that are lived in the city. These places were visited twice a week on Tuesdays and Thursdays for 4 months June-October, where through a previous survey 8 migrants were identified who do not stay in the houses for migrants in the city, so that are inhabited in the street and improvised places, which meets the criteria of the investigation.

\section{Characteristics of the study population}

The study population is composed by 8 male individuals of Mexican nationality (Table 1), between 20 and 60 years of age, and according to the previous survey live in the streets of the city of Reynosa after they have been deported from the United States, and they have lived for a period of time in the street, after being in the assistance houses.

Table 1.- Characteristics of migrants interviewed in street situations in Reynosa, Tamaulipas

\begin{tabular}{ccccc}
\hline Alias & State of Origin & Age & Residence & Time \\
\hline Juan & Hidalgo & 24 years old & Rent a room & - \\
\hline Pedro & Michoacán & 35 years old & Street & 2 years \\
José & Guanajuato & 38 years old & Street & 8 years \\
\hline Antonio & Veracruz & 39 years old & Street & 2 years \\
\hline Luis & Veracruz & 40 years old & Street & 4 months \\
\hline Santiago & Coahuila & 43 years old & Abandoned Hotel & 1 month \\
\hline Paco & Guerrero & 52 years old & Street & 5 years \\
\hline Jesús & Michoacán & 56 years old & Street & 7 years
\end{tabular}

\section{RESULTS AND DISCUSSION}

The people interviewed have lived in the United States for long periods of time of up to 15 years, and were arrested and deported by the American authorities and returned by this city and once the migrants are deported again to Mexican lands mostly without the money that they earned and looking for a place to stay, they ask themselves about what to do: return to their place of origin, try to return to the United States or stay at the border. 


\section{Migratory dynamics}

The interviewees come from the states of Michoacán, Veracruz, Guerrero, Hidalgo, Coahuila and Guanajuato; based on the data obtained, those related to the migratory dynamics they have had, which although it is not the objective of this study, they highlight how much it has impacted in their lives returning to Mexico after years in the United States.

The return to Mexico, becomes the migrants in a stressful life event, as mentioned at the beginning, the questions about "now what do I do" involve decision making, but also of living "one day at a time" trying to organize their lives to make decisions. When they were asked if they would return to their place of origin, half of them mentioned that they would return to their states of origin to see their families, however, the other half argued not to be ready to return so they keep trying to return to the United States even if they are arrested several times.

Yes I would like to return to my land, but I keep trying to cross to earn money and send it to my family but they [American authorities] have returned me (Antonio, 39, from Veracruz)

I am not yet ready to return to Michoacán and in the United States I do not have family or friends, it is not the first time that I go to "the other side" [United States] since I have been crossing for 15 years, the first for Tijuana and I went to California and I have been in Miami, North Carolina and San Francisco and there I worked laying floors and masons but I am already 7 years living here (Jesus, 56 years old, from Michoacán)

I don't know if I would return, only if I find a girl to get married, I worked in Florida in swimming pools construction and events and they [American authorities] deported me (Juan, 24, from Hidalgo)

I am from Michoacán from a town called Cerro Colorado there are about 150 inhabitants there, but I do not return because it is very bad there, although I have a daughter in Michoacán I have not raised money to send to her (Pedro, 35, from Michoacán)

Highlighting the emphasis they make on the family, this situation allows to dimension the intrapersonal issues of migrants in street situations and allows an approximation to the 
attachment relationships of these people to understand the life decisions that motivated them to undertake migration from their homes in Mexico.

I have 3 children in Veracruz and if I would like to go back to see my family, in the United States I have neither relatives nor acquaintances, in the United States I worked as a bricklayer and laying floors (Luis, 40 years old, from Veracruz)

I worked in McAllen, but I'm already 8 years living in Reynosa, yes I would return to my land (José, 38, from Guanajuato)

I would like to return to Coahuila to see my son, I have been living in Chicago for 10 years and a month ago I was deported by Matamoros and from there I came to Reynosa but I really do not know what to do (Santiago, 43 years old, from Coahuila)

Among the literature on the homeless focus on the trauma of not having a roof under which to sleep and from psychological postures stand out, becoming suddenly homeless represents a serious enough stress factor to produce some symptoms of post-traumatic stress, such as dissociative states, decreased interest in significant activities, depression, anxiety, loss of confidence and sense of personal control (Goodam, Saxe and Harvey, 1991, cited on Navarro, 2014). However, recent studies establish that the migrant population in a street situation has more resistance to mental disorders than people originating in the area (Tsai \& Gu, 2019), which makes it possible to establish the hypothesis that migrants derived from their migratory condition resist more live on the street and face vulnerable conditions, allowing them to cope with this situation.

\section{Living in the street as a migrant}

In the city of Reynosa there are places designated to assist them while they adapt to the new place and to contact their families, they go to the two migrant assistance houses of the city: La Casa del Migrante Nuestra Señora de Guadalupe and Senda de Vida, in these places provide them with food and lodging for some days, however, such assistance expires from the third day, due to the constant fluctuation of migrants in the city, it is sought to extend the service to as many migrants as possible, but they make it easier for them to contact their families in their places of origin in Mexico or in the United States, so the families can know the location of these persons. In addition, the Tamaulipeco Institute for Migrants 
(ITM), among its activities, provides information and geographic orientation, food, medical and psychological services, accommodation, clothing, legal assistance, social orientation and transportation services when needed.

I don't have a family here, it's the first time l've arrived here in Reynosa 3 or 4 months ago, they [the police] hit me at night when I slept on the street, but at La Casa del Migrante they feed me, they just let me stay 3 days, but I have struggled to work here, right now I help the planter and the owner lets me stay out there (Luis, 40, from Veracruz)

It is the first time that I emigrate, and since I was deported two years ago I came to Reynosa, here I have not suffered any abuse but it has cost me to adapt myself to the city, it is very difficult, I have stayed to sleep in the migrant's house but only they let me stay for 3 days and I also stayed in a flatbed when they give me a chance if not, on the street (Antonio, 39, from Veracruz)

It is the first time that I am in Reynosa and I have had some problems with people since they do not help you, I have stayed to sleep in the migrant's house and in an abandoned hotel (Santiago, 43 years old, from Coahuila)

Migrants in street situations improvise a place to spend the night once the period of accommodation in the assistance houses is met; it should be noted that there is a minimum population that mentions that they already live in a fixed place where they pay rent and although it is a small space they no longer sleep on the streets because informal work allows them to pay the income and food expenses.

I spent a few days in La Casa del Migrante, right now I have 6 years without seeing my family, I don't want them to know that I am here, then I was first staying in a hospital and then in the church with the Pastor [Migrant House Senda de Vida] and from there he took us to work in the harvest and feed us and it is the first time I arrived here to Reynosa I didn't know anyone when I arrived here and I no longer stay in the street right now I rent a small house (Paco, 52, from Guerrero)

Here in Reynosa I have arrived 3 times, the first time I crossed the border walking you know; I have family here in Reynosa. I don't sleep on the street. I've never had 
that need. I've always rented a room for about $\$ 700.00$ to $\$ 1000.00$ pesos (Juan, 24, from Hidalgo)

However, not everyone manages to find work or a place to live, so they sleep where they are when it gets dark and they walk the streets on the downtown in the day, waiting for other people to give them money, clothes and food.

I have about 2 years of living here in Reynosa, I sleep where the night falls (Pedro, 35, from Michoacán)

I am 8 years living in Reynosa, I sleep on the street at the foot of the statue of the Virgin of Guadalupe (José, 38, from Guanajuato)

It is the first time that I am in Reynosa and I have not had any problems since I do not mind adapting I have always been alone, I stayed to sleep in the migrant's house when I arrived and in the street (Jesus, 56 years old, from Michoacán)

This situation coincides with what was established by Avramov (1995) when he mentions that people in a street situation are those who cannot access or keep adequate accommodation, adapted to their personal, permanent situation that provides them with a stable framework of coexistence, whether for economic reasons or other social barriers, or because they present personal difficulties to lead an autonomous life. In this sense, Navarro (2014) emphasizes that the lack of a home in migrants is not the main point, but the situation in which they live, which is the cause of living on the street.

\section{Work as subsistence on the street}

When migrants have been deported and arrive in Mexico, they immediately try to place themselves in a labor market similar to what they had in the United States and vice versa, coinciding with what was found by Alarcón et al. (2009) by establishing that migrants work in jobs they know, this situation helps in the ability of individuals to face the migratory context in a place where they do not belong.

The ability to get formal employment in migrants is determined by job skills and educational level, however, this social group is generally characterized by having basic education, but 
desirable skills for agricultural work, and construction in which they are employed in the United States (Gilleland, Laurie \& Rankin, 2016) and in which they are employed temporarily in Mexico.

According to the data obtained, the majority of migrants in street situations have knowledge of masonry, construction, remodeling houses, washing cars, running errands and painting jobs and other work they did in the United States, even so, as mentioned earlier.

Sometimes I work in the planter where they let me sleep, I also work as a mason when people give me a chance and with the food that the Mothers give us. (Antonio, 39, from Veracruz)

To earn money I wash cars and run errands (Pedro, 35, from Michoacán)

Here I work on the street of whatever (José, 38, from Guanajuato)

If I have struggled to work here, right now I help the planter and the Lord lets me stay out there (Luis, 40, from Veracruz)

Here I have not had difficulties to work, right now construction work (Juan, 24 years old, from Hidalgo)

I work in painting and remodeling INFONAVIT houses, I have not had difficulties nor have I struggled to find work because they arrive here and give us work (Paco, 52, from Guerrero)

However, the difficulties in accessing formal employment are more accentuated in this social groups, in the present study it was identified that only one person suffered from alcoholism, which coincides with what was found by Tsai \& Gu (2019) where they establishes that migrants in street situations are less likely to present addictions than native-born homeless.

I don't have a job but I survive with the food that the Sister of the Migrant House (Nuestra Señora de Guadalupe) give me (Santiago, 43, from Coahuila)

When I'm not drunk, I work as a bricklayer (Jesús, 56, from Michoacán)) 


\section{Risks of living in a street situation}

The interviewed migrants mention that the most serious risk they have experienced from sleeping on the street are injuries derived from the constant aggressions by other people, as well as insults and blows by state forces such as police and soldiers and by the criminal groups of the region, coinciding with what was found by Vargas (2008) about the violence faced by migrants who violate their rights and their physical integrity.

The violence that has remained in the city of Reynosa due to the constant disputes over strategic territories for illicit trafficking in drugs, weapons and people has placed migrants in a vulnerable situation, the most remembered case is that of the 72 migrants killed in 2010 by a criminal group called Los Zetas in the municipality of San Fernando in this same Mexican state, 58 men and 14 women, in which two people survived, this event evidenced the constant vulnerability to which they are exposed and the need to guarantee the security of the local and migrant population (Aguayo, 2016).

Among the most common aggressions in addition to the blows, the "tablizas" [physical stigmas on feet and buttocks, usually with wooden slats, as typical punishment behavior of criminal groups in the region] inflicted by organized crime stand out, this situation coincides with those established by Navarro (2012) when he mentions that this condition causes migrants to live in fear and insecurity during mobility and staying in the streets.calles.

I have suffered many humiliations and blows and wounds by the police (Santiago, 43, of Coahuila)

At night they hit me because I sleep on the street (Luis, 40, from Veracruz)

They have hit me many times, they give us "tablizas" the people of the "maña" [organized crime] (Pedro, 35 years old, from Michoacán)

I've been beaten for walking at night on the street (José, 38, from Guanajuato)

It has not been difficult for me to live with people, but they have hit me, you know when you look for problems, you find them more when you are drunk [Jesus] (56 years old, from Michoacán) 
They have not treated me badly here, but I have seen that they have beaten others (Paco, 52, of Guerrero).

These events have resulted in actions by the state, with the creation of the Tamaulipeco Institute for Migrants one year after the San Fernando massacre, which, as mentioned above, seeks to guarantee Mexican or foreign migrants medical care, food, accommodation in coordination with the assistance houses and a safe return to their places of origin.

\section{CONCLUSIONS}

Although it is necessary to go deeper into the context of migrants in street situations, in the present study shows that the migrant population in the city of Reynosa is in an unfavorable context of society, derived from the high fluctuation of Mexican and foreign migrants seeking the "American Dream" and the conditions of insecurity in Mexico and especially at the border, situations that predispose them from the beginning to human rights violations during the crossing and even once they reach the border, inequalities and disadvantages become present; this vulnerability causes migrants in border cities like Reynosa to inhabit and remain in the streets, exposing themselves to attacks by criminal groups and security forces.

Representations of violence against migrants, manifest one of the most considerable problems in the phenomenon of migration, since it limits the physical and labor capacity of individuals to develop socially in a new environment and alien to their cultural costumes and traditions.

In the process of adaptability, migrants seek economic income for three possible situations: continue the journey to the United States, remain in the city indefinitely or return to their place of origin. In this period of permanence in the city, they are exposed to the consumption of alcohol and drugs, a situation that limits me the ability to face the reality of life on the street, also predisposes them to violent situations between them and that leads to considerable physical injuries.

Physical aggressions are the main risk to which they are exposed when sleeping on the street, in addition to the predisposition already mentioned for substance use, structural forces such as state police and militia occupy a considerable category as migrant aggressors, in addition to Constant permanence on the street also puts them at a 
disadvantage in terms of physical aggressions by criminal groups in the region causing serious injuries resulting from assaults, robberies and extortion.

\section{REFERENCES}

Aguayo, S. (2016). In the homelessness, Los Zetas, the State, society and the victims of San Fernando, Tamaulipas (2010), and Allende, Coahuila (2011). Center of Studies of the College of Mexico (COLMEX) and the Executive Commission of Attention to Victims (CEAV). 307 p. https://doi.org/10.24201/es.2017v35n104.1512

Alarcón, R., Cruz, R., Díaz, A., González, G., Izquierdo, A., Yrizar, G. \& Zenteno, R. (2009). The financial crisis in the United States and its impact on Mexican migration. International Migrations Vol. 5 (1), pp. 193-210. Available on: http://www.scielo.org.mx/pdf/migra/v5n1/v5n1a7.pdf.

Canales, A. \& Rojas, M. (2018). Overview of international migration in Mexico and Central America. Population and Development Series. CEPAL, United Nations and IOM. 93

p. Available in: https://repositorio.cepal.org/bitstream/handle/11362/43697/1/S1800554 es.pdf.

Center for Social Studies and Public Opinion (2015). Citizen Pulse: Human Rights for $\begin{array}{llll}\text { Migrants. } & 43 & \text { p. Available on: }\end{array}$ http://www5.diputados.gob.mx/index.php/camara/Centros-deEstudio/CESOP/Opinion-Publica/Pulso-Ciudadano/(offset)/10.

National Population Council (CONAPO) (2018). The return in the new scenario of migration between Mexico and the United States. Ministry of the Interior. 177 p. Available on: https://www.gob.mx/cms/uploads/attachment/file/39174/EIRetornoEnelNuevoEscen ariodeMigracion.pdf.

Council to Prevent and Eliminate Discrimination (COPRED) (2017). People in Street Situation. Government of the State of Mexico. 10 p. Available on: https://copred.cdmx.gob.mx/storage/app/uploads/public/5a1/ef8/35a/5a1ef835a79b a819774826.pdf. 
Correa, G. (2016). Militarization and violence in Tamaulipas. Atlas of Security and Defense of Mexico. Casede, pp. 181-189. Available on: https://www.casede.org/PublicacionesCasede/Atlas2016/Guadalupe Correa.pdf.

Delaunay, D. (2007). Relations between poverty, migration and mobility: territorial and contextual dimensions. In Population Notes of the Economic Commission for Latin America and the Caribbean (CEPAL). Year 24 (3), pp. 87-130. DOI: https://doi.org/10.18356/d4855547-es

Survey on Aggression and Abuse of Migrants (EAAM) (2015). Main results of the survey on aggression and abuse of migrants (EAAM) returned by the immigration authorities 2012, Ministry of the Interior, National Institute of Migration and El Colegio de la Frontera Norte. 23 p. Available in: https://www.colef.mx/estudiosdeelcolef/encuestaagresion-y-abuso-a-migrantes-eamm-2012/.

Survey on Migration in the Northern Border of Mexico (EMIF) (2018). Annual Results Report 2018. The Colegio de la Frontera Norte. 41 p. Available in: https://www.colef.mx/emif/informes/norte/2018/Emif\%20Norte\%20Anual\%202018.p df.

Galtung, J. (1969). Violence, Peace and Peace Research. Journal of Peace Research. Vol. 6 (3): 167-191. DOI: https://doi.org/10.1177/002234336900600301

Galtung, J. (1990). Cultural Violence. Journal of Peace Research, Vol. 27 (3), pp. 291-305. DOI: https://doi.org/10.1177/0022343390027003005

National Institute of Statistics and Geography (INEGI) (2015). Migratory Movements in Tamaulipas 2015. Federal Government. Available on: http://www.cuentame.com.mx/monografias/informacion/tam/poblacion/m migratori os.aspx?tema $=$ me\&e $=28$.

Izcara, S., (2012) Violence against immigrants in Tamaulipas, European Review of Latin American and Caribbean Studies, Vol. 93, pp. 3-24. DOI: DOI: 10.18352/erlacs.8361

Montoya, M., Granados, J. \& Jauregui, J. (2018). International Migration of Return of the United States to Mexico in a context of economic and political crisis. Population Roles. Vol. 24 (95).DOI: https://doi.org/10.22185/24487147.2018.95.08. 
Moreno, C., Espinosa, G. \& Zapata, L. (2017). Between home and asphalt: stories and life experience of inhabitants in street conditions. Lasallian Magazine of Investigation. Vol. 2 (2), pp. 65-72. DOI: 10.22507/rli.v14n2a6.

Navarro, M. (2014). The emotional experiences of homeless migrants. Northern Mental Health. Vol. 12 (48), pp. 44-52. Available on: https://dialnet.unirioja.es/servlet/articulo?codigo=4830209.

International Organization for Migration (OIM) (2013). Report on Migrations in the World 2013. The well-being of migrants and development. International Organization for $\begin{array}{lllll}\text { Migration. } & 216 & \text { p. } & \text { Available }\end{array}$ https://publications.iom.int/system/files/pdf/wmr2013 sp.pdf.

International Organization for Migration (IOM) (2010). Central American migrant children and adolescents in populations of southern Mexico. Study Mexico 2010. 222 p. Available in: http://www.corteidh.or.cr/sitios/Observaciones/11/Anexo11.pdf.

Orozco, M. \& Yansura, J. (2015). Central America in the spotlight. Migration in its relationship with development and opportunities for change, Editorial Teseo. 237 p.

Ravenstein, E. (1889). The Laws of Migration. Journal of the Royal Statistical Society. Vol. 52 (2), pp. 241-305. DOI:10.2307/2979333

Slack, J. \& Whiteford, S. (2010) Violent trips: The transformation of clandestine migration to Sonora and California, North America. Vol. 5 (2), pp. 79-107. Available on: http://www.scielo.org.mx/pdf/namerica/v5n2/v5n2a4.pdf

Tiraboschi, F. (2011). Challenges of social participation: Scope and limits of the construction of the national policy for the population in a street situation in Brazil. FLACSO editorial. 201 p. Available on: http://gaspargarcia.org.br/wpcontent/uploads/2015/02/2011-Carolina-FerroDisserta\%C3\%83\%C2\%A7\%C3\%83\%C2\%A3o-2011-Desaf\%C3\%83\%C2\%ADosde-la-participacion-social-FINAL.pdf.

Tsai, J. \& Gu, X. (2019). Homelessness among immigrants in the United States: rates, correlates, and differences compared with nativo.born adults. Public Health Journal. Vol. 68, pp. 107-116. DOI: 10.1016/i.puhe.2018.12.017 
Vargas, C. \& Villarreal, k. (2008). Violations of the rights of migrants on their journey through the northern Forces of Tamaulipas. CienciaUAT. Vol. 2 (3), pp. 41-44. Available on: https://www.redalyc.org/pdf/4419/441942911003.pdf.

Znaniecki, F. \& Thomas, W. (2004). The Polish peasant in Europe and in America. Center for Sociological Research. 3 p. Available on: http://www.fessociologia.com/files/res/4/15.pdf.

Goodman, L, Saxe, L., \& Harvey, M. (1991). Homelessness as psychological trauma. Broadening perspectives. American Psychologist. Vol. 46 (11), pp. 1219-1225. DOI: https://doi.org/10.1037/0003-066X.46.11.1219

Avramov, D. (1995). Homelessness in the European Union: Social and Legal Context of Housing Exclusion in the 1990s : Fourth Research Report of the European Observatory on Homelessness. FEANTSA. https://doi.org/10.1177/095892879600600407 